\title{
Specifications of the University Course "Methods of Teaching Mathematics in Higher Education Institutions"
}

\author{
Nina Tarasenkova* \\ Bohdan Khmelnytskyy National University at Cherkasy, Cherkasy, Ukraine \\ *Corresponding author: ntaras7@ukr.net
}

Received September 21, 2014; Revised October 30, 2014; Accepted December 14, 2014

\begin{abstract}
The article necessitates the introduction of a subject "Methods of teaching mathematics in higher education" to the undergraduate's curriculum of mathematics students. The subject curriculum is presented, its goals and objectives are described, the contents of lectures and workshops are detailed on, the contents of the independent study material are provided, and the level-related requirements to the results of the study of this discipline by the students are offered.
\end{abstract}

Keywords: master program in mathematics, training future university instructors, methods of teaching university mathematics, a special course

Cite This Article: Nina Tarasenkova, "Specifications of the University Course "Methods of Teaching Mathematics in Higher Education Institutions"." American Journal of Educational Research, vol. 2, no. 12B (2014): 1-6. doi: 10.12691/education-2-12B-1.

\section{Introduction}

Under the educational reform in Ukraine one of the main objectives of higher education is to ensure providing special training for students, cultivate their personal qualities for them to become qualified and highly skilled experts who know how to work creatively [1-10].

Teaching activities are among the masters' future careers. Therefore, it is a must that masters should acquire at least basic knowledge and skills in methods of teaching in higher education along with being well-trained in fundamental subjects [4].

The Masters' curriculum of the Mathematical department of the Bohdan Khmelnytskyy National University of Cherkasy (Ukraine) includes the course "Methods of Teaching Mathematics in Higher Education" (MTM in HEI). The course is unique for the Ukrainian Universities. Hence, the key goal of the publication is to expose the reader to the basic principles, content and methodological features of this course [3].

\section{The Main Functions of Math Teachers' Professionally Activity at University}

\subsection{The Content of Functions and Typical Problem}

In developing the program of the course "MTM in HEI" we were guided, first of all, by the analysis of the main functions and common methodological problems facing the teacher of mathematical disciplines in higher education (Table 1).

\subsection{The Main Requirements to the Results of Study}

The purpose of the course "Methods of teaching mathematics in higher education" is to form and develop students' professional knowledge, skills and abilities that provide reconstructive and varied level, and will lay the basis for the creative approach in performing professional functions in higher education institutions.

The objectives of the course "Methods of teaching mathematics in higher education" are as follows: to reveal the importance of mathematical education, ways of practical application of mathematics in various fields of knowledge, the impact of mathematics on the development of logical and visual thinking, spatial imagination and ideas, scientific outlook of students; show the relationship of methods of teaching mathematics with mathematics as a science and other disciplines; reveal the aims and objectives of teaching mathematics in higher school, peculiarities of the organization of teaching mathematics in higher education, content, methods and means of improving the quality of students' mathematical preparation; acquaint students with the changes in the forms, methods and means of training at this stage; raise a general cultural level of the students and develop their mathematical culture and the scientific worldview; shape students' professional knowledge, skills and abilities that are to provide reconstructive and varied level and form the basis of the creative approach of the future teachers to the performance of their professional functions in teaching mathematics in higher education institutions (see Table 1). 
Table 1. Main Functions and Common Methodological Problems

Facing the Teacher of Mathematical Disciplines in Higher Education

\begin{tabular}{|c|c|}
\hline \multicolumn{2}{|r|}{ Facing the Teacher of Mathematical Disciplines in Higher Education } \\
\hline FUNCTION CONTENT & A TYPICAL PROBLEM CONTENT \\
\hline $\begin{array}{c}\text { ANALYTIC-SYNTHETIC } \\
\text { ACTIVITIES }\end{array}$ & $\begin{array}{c}\text { LOGICAL-MATHEMATICAL ANALYSIS OF THE CONTENTS OF MANUALS AND COLLECTIONS OF } \\
\text { PROBLEMS IN VARIOUS SECTIONS OF HIGHER MATHEMATICS. } \\
\text { 2. LOGICAL ANALYSIS OF DIDACTIC TEACHING MATERIAL. } \\
\text { 3. METHODOLOGICAL ANALYSIS OF THE MATHEMATICAL, PSYCHOLOGICAL AND } \\
\text { PEDAGOGICAL, AND INSTRUCTIONAL MATERIALS. } \\
\text { 4. METHODOLOGICAL ANALYSIS OF TEACHING AND TRAINING AIDS AND TOOLS. } \\
\text { 5. ANALYSIS OF THE INDIVIDUAL AND GROUP POTENTIAL OF THE STUDENTS IN THE } \\
\text { PERSPECTIVE OF DIFFERENT APPROACHES TO TEACHING MATHEMATICS AND THE COURSE } \\
\text { MATERIAL SPECIFICATIONS }\end{array}$ \\
\hline PLANNING AND DESIGNING & $\begin{array}{l}\text { 1. Planning within the discipline. } \\
\text { 2. Planning within a particular training module. } \\
\text { 3. Planning within a particular semantic module. } \\
\text { 4. Planning classes of various kinds. } \\
\text { 5. Planning students' independent work. } \\
\text { 6. Teaching students to plan their own academic work in the study of different courses of Mathematics and } \\
\text { methods of teaching mathematics }\end{array}$ \\
\hline $\begin{array}{c}\text { STUDENTS' ACTIVITIES: } \\
\text { ORGANIZATION AND } \\
\text { CONTROL }\end{array}$ & $\begin{array}{l}\text { 1. Setting students on a conscious treatment of various activities in the study of mathematics courses in higher } \\
\text { education institutions: } \\
\text { a) listening to the teacher and students; } \\
\text { B) READING TEXTBOOKS, LECTURES, SCIENTIFIC AND POPULAR LITERATURE; } \\
\text { C) SOLVING VARIOUS MATHEMATICAL PROBLEMS; } \\
\text { D) WORKING INDEPENDENTLY WITH DIFFERENT LEARNING MATERIAL IN CLASS AND AT } \\
\text { HOME; } \\
\text { D) PREPARATION OF REPORTS, PRESENTATIONS AND MORE. } \\
\text { AND TRAINING AIDS. } \\
\text { 3. DIRECT CONTROL OF STUDENTS' ACTIVITIES THROUGH THE FORMATION OF CERTAIN } \\
\text { EDUCATIONAL-COGNITIVE ACTIONS OF THE STUDENTS' AND THE ACTIONS OF CONTROL } \\
\text { AND SELF-CONTROL }\end{array}$ \\
\hline $\begin{array}{l}\text { EVALUATION OF THE } \\
\text { TEACHER'S PERSONAL } \\
\text { ACTIVITY AND THE } \\
\text { STUDENTS' ACTIVITY }\end{array}$ & $\begin{array}{l}\text { 1. ORGANIZATION OF VARIOUS FORMS OF CONTROL AND CORRECTION OF THE STUDENTS' } \\
\text { TEACHING AND LEARNING ACTIVITIES IN THE STUDY OF MATHEMATICAL SCIENCES IN } \\
\text { UNIVERSITIES. } \\
\text { 2. TEACHING STUDENTS TO EVALUATE AND SELF-EVALUATE. } \\
\text { 3. MAKING SELF-ASSESSMENT AND DOING SELF-CORRECTION OF ONE'S METHODOLOGICAL } \\
\text { ACTIVITY }\end{array}$ \\
\hline
\end{tabular}

\subsection{Body of Knowledge in the Methods of Teaching Mathematics in Higher Education Institutions}

\subsubsection{The Data of Knowledge}

To be skilled in performing one's professional duties of the University mathematics professor the University graduate (master level) should possess a complex set of knowledge in the methods of teaching mathematics which includes the following:

1. Knowledge of concepts, facts and methods of the University mathematics.

2. Knowledge of the specificity of comprehensive and specializing functions of mathematics.

3. Knowledge of the logical structure of some courses of Mathematics and semantic features of their content lines.

4. Knowledge of the goals of teaching University mathematics and various aspects of setting these goals (the purposes of studying the smallest mathematical content by units, studying themes and sections; aims of studying methods of mathematics; purposes of solving mathematical problems, proving mathematical statements, etc.).

5. Knowledge of the ways of ensuring students' understanding of the purposes of learning the material of mathematical disciplines in universities (making the students motivated in training, making the instruction intelligible, making the objectives of learning personally relevant).
6. Knowledge of the specifications of the mathematical, educational and methodological problems, ways of their wording and statement in teaching University mathematics.

7. Knowledge of mathematical operations and the corresponding actions that are necessary for solving certain classes of mathematical, educational, and teaching tasks of the University mathematics.

8. Knowledge of specific methods of mathematics and mathematics teaching methods applicable in the University mathematics.

9. Knowledge of the techniques of the organization and management of students' activities in teaching University mathematics.

10. Knowledge of the math teaching tools, ways of their creation and application in the learning process in accordance with the purposes and methods of teaching University mathematics.

11. Knowledge of different forms of monitoring, assessment and adjustment of students' performance in teaching mathematics disciplines in University, including how to establish an adequate self-assessment of students.

12. Knowledge of the principles, ways and means of implementing tiered differentiation of mathematical sciences in universities.

13. Knowledge of the types, structure types and classes of University mathematics.

14. Knowledge about the specific features of independent work in mathematics in higher education. 
15. Knowledge about the specific features of the mathematics students' research.

\subsubsection{The Levels of Knowledge}

Level-related the mathematics undergraduates' knowledge of methods of teaching mathematics in higher education and quality characteristics of these levels are given in Table 2.

Table 2. Methodological Knowledge Formedness Levels

\begin{tabular}{|c|c|c|c|}
\hline $\begin{array}{c}\text { Level } \\
\text { I }\end{array}$ & Reproductive & $\begin{array}{c}\text { The use of knowledge is possible only in standard situations Simple reproduction of knowledge, a partial understanding } \\
\text { of the contents. Diffuse state of the knowledge complex. Independent and is mostly based on the models suggested in } \\
\text { the instructions }\end{array}$ \\
\hline $\begin{array}{c}\text { Level } \\
\text { II }\end{array}$ & $\begin{array}{c}\text { Reconstructive } \\
\text { and variational }\end{array}$ & $\begin{array}{c}\text { Reconstructive and variational reproduction of knowledge close to a full understanding of the contents. Partially-ordered } \\
\text { state of the knowledge complex. Independent use of knowledge is possible in standard situations and under minor } \\
\text { variations of conditions and is based on general guidelines and general heuristics }\end{array}$ \\
\hline $\begin{array}{c}\text { Level } \\
\text { III }\end{array}$ & $\begin{array}{c}\text { Reconstructive and variational reproduction of knowledge, a complete understanding of the contents. System and } \\
\text { concept state of the knowledge complex. Independent use of knowledge is possible in varied situations, it follows } \\
\text { individually-set goals, is based on the creation of personal activity programs, it is unconventional and is realized under } \\
\text { the conditions of the creative use of existing programs in the situations with considerable variations of conditions. }\end{array}$ \\
\hline
\end{tabular}

\subsection{A Set of Skills in the Methods of Teaching Mathematics in Higher Education Institutions}

To be affluent in solving typical problems of one's professional activity in the capacity of a teacher of mathematical disciplines in higher education the University graduate (master level) should master a set of skills in the methods of teaching mathematics, which includes the following skills.

\subsubsection{Skills that Provide the Occupational Function Realization "Analytic-synthetic Activities"}

1 . The ability to perform mathematical and logicalsemiotic analysis of definitions of mathematical concepts, mathematical facts (axioms, theorems, formulas and other statements), rules, algorithms, heuristic schemes, which is the object of assimilation in the study of mathematical sciences in universities.

2 . The ability to perform mathematical and logicalsemiotic analysis of mathematical problems as learning objects and learning tools.

3. The ability to define specific purposes of learning the University mathematics instructional material (concept definitions, theorems, rules, etc.).

4. The ability to perform mathematical and logicalsemiotic analysis of the content of educational material within the discipline, individual courses, training and semantic module (select core and cover material, the leading idea of the theme, the basic knowledge and skills, internal and interdisciplinary ties, etc.).

5. The ability to perform analysis of sets of the learning module mathematical problems of a University mathematical discipline: the number and quality of the tasks designed to uncover the nature of new learning objects, to form the skills for organizing mathematical activity at a student level; quantity and quality of the problems meant to motivate the students, problems and exercises for updating basic knowledge, problems for the dispersed reviewing, etc.

6 . The ability to perform mathematical, semiotic and methodical ranging of the mathematical problems of the University mathematics.

7. The ability to identify key training tasks within the University mathematics courses and corresponding educational and cognitive activities that correspond to them.
8. The ability to set the methodical tasks within some University mathematics discipline.

9. The ability to select basic methods, techniques, forms and means to teach a particular body of educational and contents module within some University mathematics course.

10. The ability to determine the forms of monitoring and assessing the progress and results of the students' academic performance in mastering the mathematical discipline.

11. The ability to summarize and review mathematical, psychological, pedagogical, and methodical articles and guides.

12. The ability to identify individual students' learning opportunities in mathematics and form homogeneous and heterogeneous academic groups.

\subsubsection{Skills that Provide the Occupational Function Realization "Planning and Designing"}

1. The ability to design a model of the methodical system (objectives, contents, methods and forms of teaching aids) of the study of some semantic unit of a university mathematics course (at the level of a separate learning object and a learning module).

2. The ability to differentiate the requirements to the results of mastering the instructional material of the University mathematics course.

3. The ability to develop a plan of a particular University mathematics discipline study, the ability to plan within a particular learning module.

4. The ability to create a set of questions for reviewing in studying a certain University mathematics discipline.

5. The ability to create a system of exercises for updating students' basic skills in University mathematics in the classroom.

6. The ability to construct counter-examples to the system of concepts (mathematical facts, mathematical performance) studied within a separate learning and semantic modules of the University mathematics discipline.

7. The ability to select the problems meant for: different stages of the formation of mathematical concepts, studying mathematical facts, methods, techniques and rules that are the objects of assimilation within a separate learning and content module of the University mathematics; teaching of how to prove mathematical statements; developing the skills to apply the acquired knowledge in standard and other situations. 
8. The ability to compose systems of questions designed to uncover the contents of the new instructional material, to master the acquired skills, to test students' knowledge of orally and in a written form.

9. The ability to compose and compile tests, independent and control assignments of educational and monitoring nature.

10. The ability to select material for lectures, practical classes and to develop a detailed synopsis or outline classes.

11. The ability to select the literature to explore a particular issue (theorems, problems, and educational content modules of the course) and make the appropriate filing.

12. The ability to develop tutorials and manuals.

13. The ability to prepare visual aids, handouts, etc..

2.4.3. Skills that Provide the Occupational Function Realization "Students' Activities in Learning Mathematics: Organization and Monitoring"

1. The ability to provide motivation for the study of specific teaching material (topics, mathematical problems, theorems, etc.) of the University mathematics.

2. The ability to ensure students' understanding of the purposes of learning the material of mathematical disciplines in universities - revealing the feasibility and importance of personal learning outcomes.

3. The ability to form students' cognitive interest to studying mathematics as a whole and that of its individual components.

4. The ability to apply techniques of asking questions in varied situations.

5. The ability to search for the ways of solving mathematical problems, proving mathematical statements and more.
6. The ability to work with a tutorial or a manual, tables and other related materials, as well as to teach the students to do it.

7. The ability to place the material on the board, arrange the process of the solution of the problem and the proof of mathematical statements, etc., to teach the students to do it.

8. The ability to use different techniques to respond to students' responses.

9. The ability to use a system of questions, exercises and problems designed to train students to perform analysis, synthesis, generalization, specification, comparison, division, classification and more.

2.4.4. Skills that Provide the Occupational Function Realization "Evaluation of One'S Personal Activities and Students' Activities in Teaching and Learning Mathematics Disciplines"

1. The ability to analyze students verbal responses, assess them and teach the students to do it.

2. The ability to assess training or monitoring quizzes, analyze their results.

3. The ability to teach students to find and correct errors in written papers..

4. The ability to use different types, forms, methods and means of control and corrections of students' knowledge.

5. The ability to analyze a lesson considering its place in the system of classes, objectives and characteristics of its instructional and educational material.

\subsubsection{The Levels of Skills}

Level-related the mathematics undergraduates' skills in methods of teaching mathematics in higher education and quality characteristics of these levels are offered in Table 3.

Table 3. Methodological Skills Formedness Levels

\begin{tabular}{|c|c|c|}
\hline $\begin{array}{l}\text { Level } \\
\text { I }\end{array}$ & Reproductive & $\begin{array}{c}\text { The students become aware of the purpose of the performance of a separate methodical of instructional-cognitive action, } \\
\text { they assess its operational composition. } \\
\text { The students search for the ways of performing some mathematical operations, mostly based on the sample offered in the } \\
\text { instruction }\end{array}$ \\
\hline $\begin{array}{l}\text { Level } \\
\text { II }\end{array}$ & $\begin{array}{l}\text { Reconstructive } \\
\quad \text { and } \\
\text { variational }\end{array}$ & $\begin{array}{c}\text { The students become aware of the purpose of the performance of a methodical of instructional-cognitive action, they assess } \\
\text { its operational composition. } \\
\text { The search for the ways of performing mathematical operations is made based on the employment of general } \\
\text { recommendations and general heuristics } \\
\text { Some formed methodical skills or their complexes are transferred to bigger blocks of instructional material (mathematical } \\
\text { method, themes, set of mathematical problems, etc.) }\end{array}$ \\
\hline $\begin{array}{l}\text { Level } \\
\text { III }\end{array}$ & Creative & $\begin{array}{c}\text { Being aware of the purpose of the performance of methodical or instructional-cognitive operation and its operational body } \\
\text { assessment, there takes place an independent choice and creative use of different methods and ways of methodical activities } \\
\text { and operations respective of varied situations in teaching mathematics. New ways and skills of methodical activities take } \\
\text { place }\end{array}$ \\
\hline
\end{tabular}

\subsection{The Peculiarities of Course "MTM in} HEI"

Academic Discipline "Methods of teaching mathematics in higher education institutions" is a compulsory course in preparing students for the qualification of "Master" as "Math 0801". This course is offered to the undergraduates in the 1st year of study. It comprises 54 hours of which 12 hours are allocated for a course of lectures, 20 hours are allocated for seminars, and 22 hours are allocated for the students' self-study.

\subsubsection{The Content of Modules}

The curriculum is divided into two content modules. Here we offer the topics and subject content of the lectures.

\subsubsection{Topical Module 1. Methods of Teacher-guided} Mathematical Training of University Students

Topic 1.1. Aims and objectives of teaching mathematics in higher education institutions. Standardization of students' mathematical training.

1. Aims and objectives of University mathematics.

2. The structure of University mathematical education.

3. Standardization of students' mathematical training.

4. Psychological and pedagogical fundamentals of University mathematics. 
5. Comprehensive, systematic, functional and semiotic approaches to University mathematics.

6. Differentiation and individualization of teaching.

7. Peculiar features of the University mathematics methodological system.

Topic 1.2. Specificity of preparing and conducting University lectures in mathematical sciences.

1. Peculiar features of the lectures on mathematical subjects.

2. Types of lecture presentation.

3. Ways and means of enhancing students' cognitive activity at the lectures on mathematics.

4. Steps of the teacher's getting ready for the lecture.

5. Specificity of reading lectures.

Topic 1.3. Methods of forming students' knowledge, skills, and abilities at practical classes in mathematics.

1. Objects of mastering in the University mathematics.

2. Students' knowledge, skills and abilities as the product of learning activities.

3. Logical-mathematical analysis of the content of teaching materials and tasks.

4. Peculiarities of the selection of the learning content to be delivered at practical lessons.

5. Updating students' background knowledge at the lesson.

6. Perfecting students' knowledge, skills and abilities.

7. System of the preparation of the mathematics teacher for practical classes.

\subsubsection{Topical Module 2. Students' Independent Work in Mathematics.}

Topic 2.1. Methodical system of students' independent work in the study of mathematical sciences.

1. The purpose of the students' independent work.

2. Methods of selecting the material for the independent work.

3. Learning methods that are applied in the independent work.

4. Selection and application of general and specific organizational forms.

5. Methods of the development of learning tools and their use in students' self-study.
Topic 2.2. Control and correction of the students' academic performance in mathematics

1. The purpose and objectives of control and correction during the formation of students' mathematical knowledge, skills and abilities.

2. Functions of control and correction in learning mathematics.

3. Components of the process of preparing and realizing monitoring and correcting the students' educational achievements.

4. Types of control.

5. Types of control activities as related to the activities of the subject of control.

6. Types of control activities as related to its placement in the learning process.

7. Forms of control.

8. Ways to control.

9. Means of controls.

10. Assessment scale.

\subsubsection{The Themes of Practical Training}

The course "MTM in HEI" foresees practical training on the following topics:

1. Logical-mathematical analysis of teaching materials and tasks. Logical and didactic analysis.

2. The system of lecture preparing.

3. Development of computer support for lecture presentation.

4. Methods of updating the students' basic knowledge.

5. Methods of testing the knowledge, skills and abilities of students during practical classes.

6. Organization of practical training using ICT.

7. Construction of differentiated sets of exercises and problems designed for self-study students.

8. Methods for inspection and assessment of students' academic performance. Testing.

9. Reviewing scientific and methodological publications.

10. Tests.

\subsubsection{The Content of the Students' Self-study}

Curriculum allocates as many as 22 hours for the students' independent work. Thus, it becomes very important to clearly define the contents of the independent work and its time limits. We offer the following sets of tasks for the course "MTM in HEI" (see Table 4).

Table 4. Tasks for the Independent Work

\begin{tabular}{|l|c|c|}
\hline$\#$ & Qask Content & Quantity of hours \\
\hline 1 & Solving mathematical problems & 6 \\
2 & Solving methodical problems (topic: "Guidelines for preparing lectures") & 4 \\
3 & Solving methodical problems (topic: "Guidelines for preparing practical classes") & 4 \\
4 & Solving methodical problems (topic: Organization of the students' independent studies") & 4 \\
5 & Solving methodical problems (topic: Control and corrections of the students' academic performance") & 4 \\
\hline
\end{tabular}

Alongside with general tasks for the independent work the students are offered to perform two compulsory individual educational and research assignments. One of the problems relates to the issues of the general methods of teaching University mathematics. The second task is to prepare an abstract for general and specific methods of teaching University mathematics.

\section{Conclusion}

In conclusion we should admit that the problems of developing a system of tasks and exercises for the course "MTM in HEI" require further research. Their implementation will allow of adding contents to the masters' learning and promote more effective preparation of the future University teachers.

\section{References}

[1] Stepko, M.F., Bolyubash, Ya.Ya., Shikarook, V.D., Hrubinko, V.V., Babyn, I.I., (compilers) "Bologna process in facts and 
documents", Publishing house of the V. Hnatyuk TSPU, KyivTernopil, 2003, 52.

[2] Kuzminskyy, A.I., Tarasenkova, N.A., Akulenko, I.A, Scientific basis of future mathematics teacher methodological training, Publishing house of Bogdan Khmelnytskyy National University at Cherkasy, Cherkasy, 2009, 320

[3] Tarasenkova, N.A., Methods of teaching Mathematics in higher educational institutions: Curriculum, Publishing house of Bogdan Khmelnytskyy National University at Cherkasy, Cherkasy, 2005, 24.

[4] Slepkan', Z.I., Scientific basis of educational process in higher education, M. Drahomanov NPU, Kyiv, 2000, 400.

[5] Tarasenkova, N., "Peculiar Features of Verbal Formulations in School Mathematics," Global Journal of Human-Social science: G: Linguistics \& Education, 14 (3, Version 1.0), 61-67, 2014.

[6] Tarasenkova, N., "The quality of mathematical education in the context of Semiotics," American Journal of Educational
Research, 1 (11: Special issue Ensuring the quality of higher education), 464-471, Nov. 2013.

[7] Tarasenkova, N., Akulenko, I., "Determination of students' beliefs as one of the aspects of competence oriented system of mathematics teachers' methodical preparation," American Journal of Educational Research, 1 (11: Special issue Ensuring the quality of higher education), 477-483, Nov. 2013.

[8] Tarasenkova, N., Chashechnikova, O., Bogatyreva, I., "Peculiar Properties of Mathematics Teacher Training in Ukraine," American Journal of Educational Research, 1 (11: Special issue Ensuring the quality of higher education), 490-495, Nov. 2013. doi: 10.12691/education-1-11-6.

[9] Tarasenkova, N. A, Using sign and symbolic means in teaching mathematics: Monograph, "Vidlunnya-Plyus", Cherkasy, 2002, 400.

[10] Tarasenkova, N. A, Kolomyets, O. M., "Structure of teaching Geometry to the Mathematics students in Ukrainian Universities", Zeszyty Naukove WSHE, XXXIV (Nauki Pedagogiczne), Wloclavek, 205-212, 2012. 